\title{
Challenging nanoparticles: a target of personalized adhesion prevention strategy
}

This article was published in the following Dove Press journal:

International Journal of Nanomedicine

15 July 2014

Number of times this article has been viewed

\section{Ospan A Mynbaev ${ }^{1-4}$ \\ Marina Yu Eliseeva ${ }^{2}$ \\ Antonio Malvasi ${ }^{5}$ \\ Andrea Tinelli ${ }^{6}$}

'International Translational Medicine and Biomodeling Research Team, MIPT Center for Human Physiology, Department of Applied Mathematics, Moscow Institute of Physics and Technology (State University), Dolgoprudny, Moscow Region, Russia; ${ }^{2}$ Department of Obstetrics, Gynecology and Reproductive Medicine, Peoples' Friendship University of Russia, Moscow, Russia; ${ }^{3}$ Laboratory of Pilot Projects, Moscow State University of Medicine and Dentistry, Moscow, Russia; ${ }^{4}$ The New European Surgical Academy, Berlin, Germany; ${ }^{5}$ Department of Obstetrics and Gynecology, Santa Maria Hospital, Bari, Italy; ${ }^{6}$ Department of Obstetrics and Gynaecology, Division of Experimental Endoscopic Surgery, Imaging, Minimally Invasive Therapy and Technology, Vito Fazzi Hospital, Lecce, Italy
Correspondence: Ospan A Mynbaev Kremenchugskaya str, 3-4-198 Moscow, I2 I352, Russia

Tel +74997926927;+79I6I27I546

Email ospanmynbaev@hotmail.com

\section{Dear editor}

With great interest we have read an article by $\mathrm{Wu}$ et al ${ }^{1}$ recently published in the International Journal of Nanomedicine aimed to estimate cytotoxicity, toxicity, and histopathological changes, as well as the postsurgical antiadhesion potential of biodegradable and thermosensitive micelles by combining in vitro and in vivo models.

Our congratulations to $\mathrm{Wu}$ et $\mathrm{al}^{1}$ for their new, precisely designed, and promising study of nanoparticles used in the prevention of postsurgical adhesions. Even more so when we know that in most clinical studies the adhesion prevention adjuvants have failed. Taking into account medical and financial problems associated with postsurgical adhesions worldwide in the health care system, new developments in this area are welcomed and call for further investigation.

We do not question the definite study question and design: the experimental models are precisely formed and trigger correctly described results, a knowledgeable discussion and subsequent reasonable conclusions in line with their achievements.

However, in our opinion, for these biodegradable and thermosensitive micelles to be recommended for further clinical applications, experimental studies should be designed examining different doses of nanoparticles in order to establish the optimal dose of micelles, an evaluation of the impact of these materials in different time points after their application, ie, 14, 21, 28 days, as well as their long-term impact after 6 and 12 months.

The impact of these particles on embryos in in vivo models should also be evaluated: do these particles last longer or do they have an impact on uterine wall tissue?

In the future a personalized adhesion prevention strategy could be developed, with application of state of the art technologies, taking into account genetic and constitutional predisposing factors of the patients undergoing these surgical procedures, with targeted predisposing genetic and constitutional conditions. ${ }^{2}$ Subsequently, these biodegradable and self-assembling micelles could be designed to contain medication such as recombinant tissue plasminogen activator (rtPA), ${ }^{3} t P A$ genes, inhibitors of plasminogen activator inhibitor-1 (PAI-1) genes, or other cytokines activating the expression of individually targeted genes at certain times after surgery in order to lyse and remove temporary fibrinogenous adhesions.

In conclusion, biodegradable micelles containing certain medications should be a basis for future personalized adhesion prevention strategies. 


\section{Disclosure}

The authors report no conflicts of interest or financial ties to disclose in regards to this communication.

\section{References}

1. Wu Q, Li L, Wang N, et al. Biodegradable and thermosensitive micelles inhibit ischemia-induced postoperative peritoneal adhesion. Int $J$ Nanomedicine. 2014;9:727-734.
2. Arslan E, Talih T, Oz B, Halaclar B, Caglayan K, Sipahi M. Comparison of lovastatin and hyaluronic acid/carboxymethyl cellulose on experimental created peritoneal adhesion model in rats. Int J Surg. 2014;12(2): $120-124$.

3. Nair S, Saed GM, Atta HM, et al. Towards gene therapy of postoperative adhesions: fiber and transcriptional modifications enhance adenovirus targeting towards human adhesion cells. Gynecol Obstet Invest. 2013; 76(2):119-124.

International Journal of Nanomedicine

\section{Publish your work in this journal}

The International Journal of Nanomedicine is an international, peerreviewed journal focusing on the application of nanotechnology in diagnostics, therapeutics, and drug delivery systems throughout the biomedical field. This journal is indexed on PubMed Central, MedLine, CAS, SciSearch ${ }^{\circledR}$, Current Contents ${ }^{\circledR} /$ Clinical Medicine, Elsevier Bibliographic databases. The manuscript management system is completely online and includes a very quick and fair peer-review system, which is all easy to use. Visit http://www.dovepress.com/ testimonials.php to read real quotes from published authors. 